\title{
ARTICLES
}

\section{Expression and Localization of the Annexins II, V, and VI in Myocardium from Patients with End-Stage Heart Failure}

\author{
Dmitri Benevolensky, Yulia Belikova, Reza Mohammadzadeh, Pascal Trouvé, \\ Françoise Marotte, Françoise Russo-Marie, Jane-Lyse Samuel, and \\ Danièle Charlemagne
}

\author{
INSERM (DB, YB, RM, PT, FM, J-LS, DC), U-127, IFR Circulation, Lariboisière Hospital, and U-332 INSERM (FR-M), \\ UFR Cochin Port-Royal, Paris, France; and Cardiology Research Center (DB, YB), Moscow, Russia
}

\begin{abstract}
SUMMARY: Annexins II, V, and VI belong to a family of $\mathrm{Ca}^{2+}$-dependent phospholipid-binding proteins that have been involved mainly in signal transduction, differentiation, membrane trafficking events, or binding to the extracellular matrix, or that might be effective as $\mathrm{Ca}^{2+}$-channels. They are abundant in the mammalian myocardium and might play a role in ventricular remodeling and altered calcium handling during heart failure. To test this hypothesis, we compared the expression and distribution of these annexins in nonfailing $(n=9)$ and failing human hearts with idiopathic dilated cardiomyopathy $(n=11)$. Northern blot and slot blot analysis were used to determine the annexin mRNA levels and Western blots were used to quantify the amounts of annexin proteins. Distribution of annexins was studied by immunohistofluorescence labeling and compared with that of a sarcolemmal marker $\left(\mathrm{Na}^{+} / \mathrm{K}^{+}\right.$-ATPase) and of a myofibrillar protein ( $\alpha$-actinin). We showed that nonfailing hearts contained a higher amount of annexin VI than of annexin V or II $(13.5 \pm 1.8,3.7 \pm 0.2$, and $2.5 \pm 0.5 \mu \mathrm{g} / \mathrm{mg}$ protein, respectively). In failing hearts, there was a parallel increase in both mRNA and protein levels of annexin II (146\% and 132\%, $p<0.05$, respectively) and annexin V (152\%, $p<0.01,147 \%, p<0.005$, respectively); the protein level of annexin VI was also increased $(117 \%, p<0.05)$, whereas the increase of its mRNA level was statistically insignificant. We observed a predominant localization of annexin II in interstitium, and of annexins $\mathrm{V}$ and $\mathrm{VI}$ in cardiomyocytes at the level of the sarcolemma, T-tubules, and intercalated disks in nonfailing hearts, whereas in failing hearts enlarged interstitium contained all three annexins. Furthermore, annexin $V$ staining at the level of cardiomyocytes almost disappeared. In conclusion, we showed that heart failure is accompanied by marked overexpression of annexins II and V, as well as translocation of annexin V from cardiomyocytes to interstitial tissue. The data suggest that annexins may contribute to ventricular remodeling and annexin $\mathrm{V}$ to impaired $\mathrm{Ca}^{2+}$ handling in failing heart. (Lab Invest 2000, 80:123-133).
\end{abstract}

$T$ he annexins constitute a family of proteins that have a distinctive property to bind phospholipids in a calcium-dependent way (for reviews see Raynal and Pollard, 1994; Waisman, 1995). Although the exact biological role of the annexins remains unknown, they have been involved in various intra- and extracellular processes, including mitogenic signal transduction, differentiation, membrane trafficking events, $\mathrm{Ca}^{2+}$ fluxes, and binding to the extracellular matrix. Myocardial annexins have been mostly studied

\section{Received July 12, 1999.}

This work was supported by grants from Association Française contre les Myopathies, Fédération Française de Cardiologie, INSERM (PECO), and Russian Foundation for Basic Research (grant 96-04-49640). YB was supported by le Conseil Régional d'Ile de France (poste vert-INSERM) and DCH by CNRS.

Address reprint requests to: Dr. Danièle Charlemagne, IFR Circulation, $U$ 127 INSERM, Université D. Diderot, 41 Bd de la Chapelle, 75475 Paris Cedex 10, France.Fax: 331487423 15; E-mail: d.charlemagne@ inserm.lrb.ap-hop-paris.fr in animal species in which annexins $\mathrm{II}, \mathrm{V}$, and $\mathrm{VI}$ are particularly abundant. The annexin II has been found in rat (Jans et al, 1995), bovine (Zeng et al, 1993), and guinea pig (Trouvé et al, 1999) myocardium. In different tissues, annexin II has been reported to bind collagen, to promote contacts between vesicles, and to be involved in regulation of cell-extracellular matrix interactions (Waisman, 1995). Another important feature of annexin II is its inhibitory activity on G proteinregulated $\mathrm{ip}_{3}$ production, suggesting a role in the development of hypertension (Schelling et al, 1996). Annexins $\mathrm{V}$ and $\mathrm{VI}$ are the major annexins in porcine (Pula et al, 1990), bovine (lida et al, 1992; Wang et al, 1993; Zeng et al, 1993), rat (Doubell et al, 1993; Jans et al, 1995; Wang et al, 1995), and guinea pig (Trouvé et al, 1999) myocardium. Annexin $V$ is able to form voltage-gated $\mathrm{Ca}^{2+}$ channels (Pollard et al, 1992) and to modulate activity of protein kinase $\mathrm{C}$ and phospholipase $A_{2}$ (Dubois et al, 1998; Mira et al, 1998; Van Bilsen et al, 1992). In myocardium, the localization of 
A

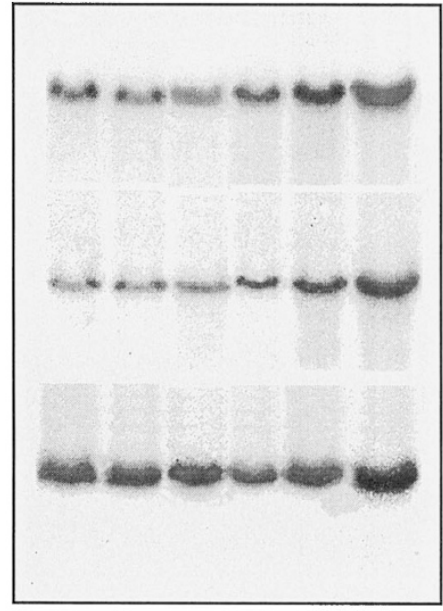

$N \quad N \quad N \quad F \quad F \quad F$

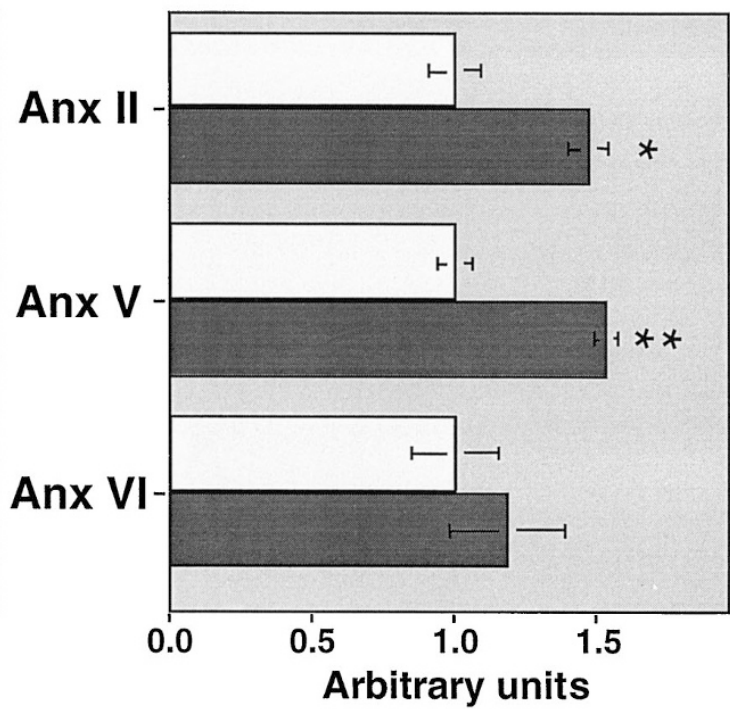

\section{Figure 1.}

mRNA analyses of cardiac annexins II, V, and VI. A, Representative Northern blot analysis of annexin II (Anx II), annexin V (Anx V), and annexin VI (Anx VI) mRNA from nonfailing ( $M$ ) and failing human hearts with idiopathic dilated cardiomyopathy (IDCM) (F). Each lane contained equal amounts (25 $\mu \mathrm{g})$ of total RNA. B, Bar graph shows changes of mRNA levels of annexin II, V, and VI in failing hearts. mRNA levels were measured in nonfailing (light bars; $n=9)$ and failing (dark bars; $n=$ 11) hearts by slot blot, and normalized to poly $\left(\mathrm{A}^{+}\right) \mathrm{RNA}$. Values are mean $\pm \mathrm{SEM} ;{ }^{*} p<0.05$, ${ }^{\star \star} p<0.01$, compared with nonfailing hearts.

annexin $\mathrm{V}$ is not clearly established: the presence of annexin $V$ was first reported in endothelium and fibroblasts (Van Bilsen et al, 1992), then in myocytes in which it has been detected either in cytosol (Jans et al, 1995), in membranes (Luckcuck et al, 1997; Trouvé et al, 1999), or associated with Z-lines (Trouvé et al, 1999; Wang et al, 1995). Annexin VI has been localized in rat, bovine, and guinea pig hearts mainly in sarcolemma and intercalated discs of cardiomyocytes (Doubell et al, 1993; lida et al, 1992; Luckcuck et al, 1997; Trouvé et al, 1999).

In heart pathophysiology, few reports deal with annexin expression or suggest a possible role in heart failure. Overexpression of annexin $\mathrm{VI}$ in the heart of transgenic mice was shown to result in dilated cardiomyopathy (Gunteski-Hamblin et al, 1996) with impaired contractility and intracellular $\mathrm{Ca}^{2+}$ turnover (Song et al, 1995). Increases in the levels of annexins II, V, and VI were found in hypertensive guinea pigs at the onset of heart failure (Trouvé et al, 1999) and increases of annexins II and V, together with a decrease of annexin VI in failing human heart (Song et al, 1998). However, potential roles for annexins in heart failure cannot be considered without establishing their precise distribution in human heart and during heart failure.

The aim of this study was to perform parallel studies on expression and distribution of annexins II, V, and VI in failing (due to idiopathic dilated cardiomyopathy; IDCM) and nonfailing human hearts. Quantitative analysis showed coordinate upregulation of both mRNA and protein levels of annexins II and $\mathrm{V}$ in samples from failing hearts. In immunohistochemical studies, we showed that an increase in annexins II, V, and VI content in failing human heart was accompanied by their accumulation in cardiac interstitium, whereas staining of cardiomyocyte membranes with antibodies to annexin $\mathrm{V}$ was almost lost.

\section{Results}

\section{Annexins II, V, and VI mRNA in Nonfailing and Failing Human Myocardium}

Northern blot analysis of mRNA extracted from human myocardium and hybridization with specific probes for annexins II, V, and VI demonstrated corresponding

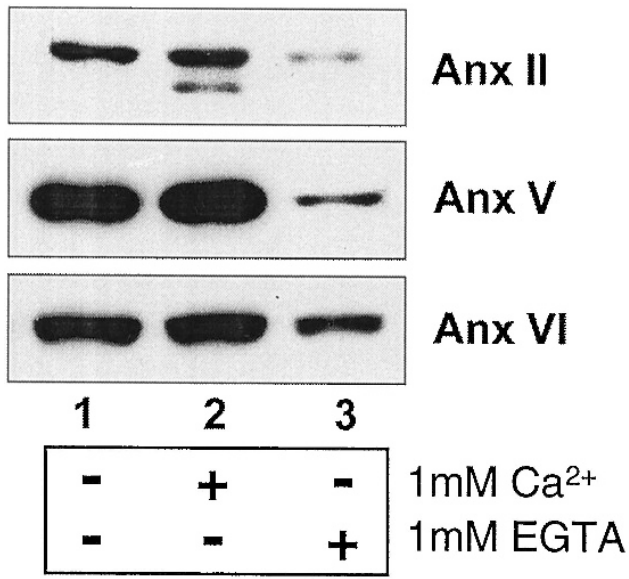

Figure 2.

The effect of $\mathrm{Ca}^{2+}$ concentration on the annexins content of crude particulate preparation (CPP). Western blot analysis of annexin II (Anx II), annexin V (Anx $V$, and annexin VI (Anx VI) in CPP (10 $\mu$ g of protein) isolated as described in "Materials and Methods" (lane 1), in the presence of $1 \mathrm{mM} \mathrm{Ca}^{2+}$ (lane 2), or in the presence of $1 \mathrm{mM}$ EGTA (lane 3). 
bands (annexin II, $1.25 \mathrm{~kb}$; annexin V, $1.35 \mathrm{~kb}$; annexin VI, $2.3 \mathrm{~kb}$ ) (Fig. 1A). The bands of annexin II and annexin $\mathrm{V}$ were larger in three different failing hearts compared with nonfailing hearts, whereas no obvious difference in annexin VI band was observed.

Quantification of annexin mRNA were further carried out by slot blot analysis (Fig. 1B). We found a significant increase in mRNA levels (normalized to poly $(\mathrm{A}+) \mathrm{RNA})$ for annexins II $(146 \pm 6 \%$; $p<0.02$; $n=$ 11) and $V(152 \pm 15 \% ; p<0.01 ; n=11)$ in failing comparing with nonfailing hearts $(n=9)$. A tendency toward an increase in annexin $\mathrm{VI}$ mRNA content (120 $\pm 13 \% ; n=11)$ was statistically insignificant.

\section{Quantification of Annexins II, V, and VI Proteins in Human Myocardium}

Western blot analysis was used to quantify the annexins in crude particulate preparations (CPP) of cardiac tissue (see "Methods") which contained all of the membrane-bound annexins. Because it was known that annexins could be partially extracted by EGTAcontaining solution (Trotter et al, 1995), we tested whether the presence or absence of $\mathrm{Ca}^{2+}$ during isolation of CPP might modify the yield of annexins (Fig. 2). Compared with CPP prepared without added $\mathrm{Ca}^{2+}$ (lane 1), there was no significant increase in the annexin content in the presence of $1 \mathrm{mM} \mathrm{Ca}^{2+}$ (lane 2) in homogenization medium, but under this condition annexin II appeared as two bands probably generated by activated proteolysis. In the presence of $1 \mathrm{~mm}$ EGTA (lane 3), some but not all of the annexins were extracted from CPP, and annexin VI seemed to be the most resistant to EGTA extraction. Thus, the amount of annexins in human heart sample was determined in CPP with neither EGTA nor $\mathrm{Ca}^{2+}$ added.

Figure 3 shows Western blot analysis of annexins II, $\mathrm{V}$, and $\mathrm{VI}$ in CPP from nonfailing hearts. Nonspecific protein staining of the membrane with Coomassie blue (Fig. 3A) revealed multiple bands in lanes with CPP (lanes 1 to 3 ) and two bands for the mixture of pure

\section{A. Coomassie blue staining}
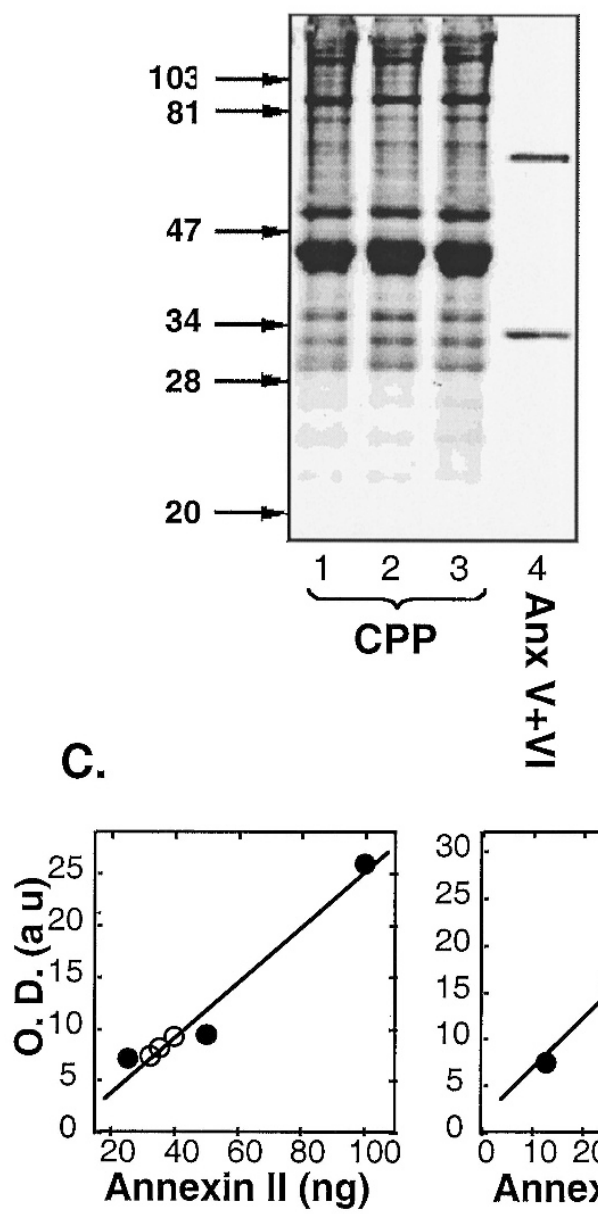

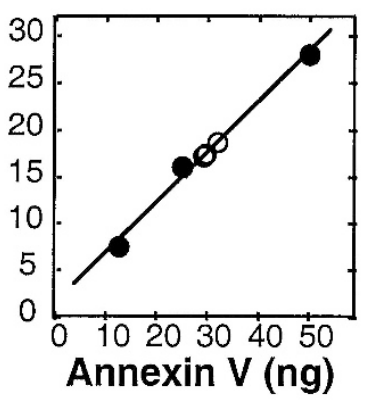

\section{B. Immunostaining}
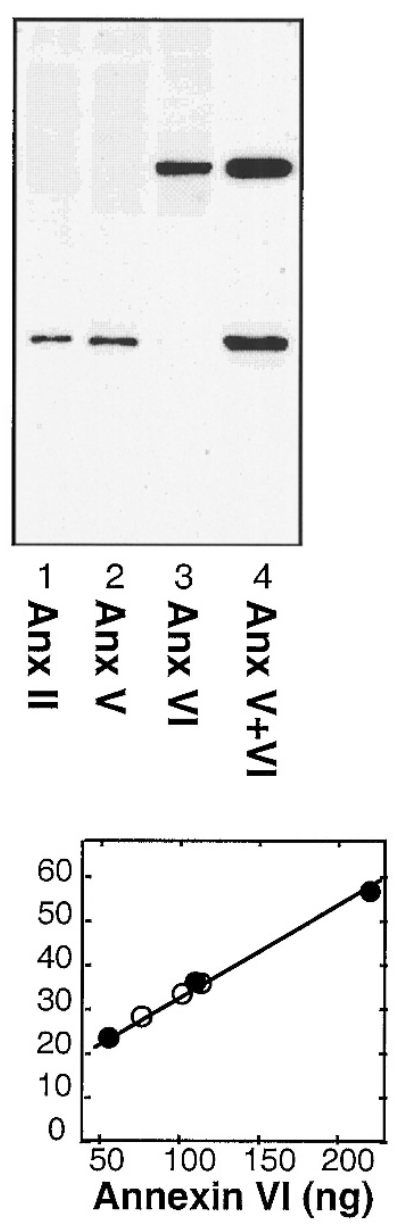

Figure 3.

Quantification of annexins II, V, and VI in CPP from nonfailing myocardium by Western blot analysis. A, Coomassie blue staining of the membrane. Lanes 1 to 3 , CPP $(10 \mu \mathrm{g})$; lane 4 , a mixture of pure annexins $\mathrm{V}$ and $\mathrm{VI}(50 \mathrm{ng}+100 \mathrm{ng})$. Position of molecular weight markers (in $\mathrm{kD})$ is shown by arrows. B, Immunostaining: the membrane was cut out and treated with antibodies to annexin II (lane 1), annexin V (lane 2), annexin VI (lane 3), and a mixture of antibodies to annexin V and annexin VI (lane 4). C, Quantification of annexins in human hearts. CPP samples from nonfailing hearts (10 $\mu \mathrm{g}$ protein, hollow circles) were run in parallel with different amounts of pure annexin (solid circles). 
annexins $\mathrm{V}$ and $\mathrm{VI}$ (lane 4). After immunostaining of each lane, we observed one band after reaction with each of the anti-annexin antibodies and two bands in the last lane after reaction with both anti-annexin $\mathrm{V}$ and VI antibodies (Fig. 3B). The apparent electrophoretic mobility of annexin II, V, and VI was 36, 32, and $68 \mathrm{kDa}$, respectively. The corresponding apparent molecular weights were identical to those obtained for the pure human annexins.

For quantification of annexins II, V, and VI, specific bands in CPP were compared with known annexin concentrations on the same Western blot (Fig. 3C). Integrated density of the spots on ECL film had linear dependence on the amount of protein applied within the chosen concentration range. All of the measured samples were well within the calibration curve. It has been determined that protein content for annexins II, $\mathrm{V}$, and $\mathrm{VI}$ was $3.7 \pm 0.2(n=4), 2.5 \pm 0.5(n=6)$, and $13.5 \pm 1.8 \mu \mathrm{g} / \mathrm{mg}(n=6)$, respectively, in nonfailing human myocardium.

\section{Comparison of Annexin Levels in Nonfailing and Failing Human Myocardium}

Annexins and sarco-endoplasmic reticulum $\mathrm{Ca}^{2+}$ ATPase (SERCA; a marker of heart failure [Hasenfuss et al, 1994]) contents of nonfailing and failing hearts were compared by Western blot analysis (Fig. 4A). One specific band of annexin II, V, and VI was detected in CPP from nonfailing as well as from failing hearts. The signals of annexin II and annexin V were stronger in failing compared with nonfailing hearts, whereas there was no obvious difference in the level of annexin VI. In addition, a decrease in the amount of SERCA was observed in all of the failing hearts.

The bar graph in Figure 4B shows that, compared with nonfailing hearts, the amounts of annexins II, V, and $\mathrm{VI}$ increased in failing myocardium to $132 \pm 9 \%$ $(p<0.05), 147 \pm 7 \%(p<0.01)$, and $117 \pm 5 \%(p<$
0.05), respectively, whereas the amount of SERCA dropped substantially to $56 \pm 12 \%$ ( $p<0.05)$, as reported for similar human tissue preparations (Hasenfuss et al, 1994).

\section{Immunolocalization of Annexins in Nonfailing and Failing Human Heart}

The distribution of annexins II, V, and VI in cryosections of cardiac tissue was analyzed by immunofluorescence and was compared with that of $\alpha$-actinin as a myofilament marker and of $\mathrm{Na}^{+} / \mathrm{K}^{+}$-ATPase as a sarcolemma marker.

Annexin II was not detected in myocytes but was present in the endothelium (both vascular [Fig. 5A] and endocardial) and in the interstitium of normal myocardium (Fig. 5B). In failing hearts, an intense labeling of annexin II was observed in the interstitium (Fig. 5C). Double immunofluorescence study of transverse section at higher magnification showed that annexin II was mainly present (Fig. 5E) in places in which $\alpha$-actinin was absent (Fig. 5F).

Annexin V (Figs. 6 and 7) in nonfailing hearts was localized mainly at the level of sarcolemma and in the endothelial cells (data not shown). Comparison of annexin $\mathrm{V}$ and $\mathrm{Na}^{+} / \mathrm{K}^{+}$-ATPase labeling in nonfailing hearts is shown in Figure 6. A similar distribution of both proteins was observed in longitudinal tissue sections (Fig. 6, A and D) at the level of sarcolemma and intercalated discs. Furthermore, magnification of longitudinal sections (Fig. 6, B and E) showed, for both antigens, regular intracellular staining pattern of dotted transversely oriented narrow bands that coincided with the sarcomeric $\alpha$-actinin labeling and that supported the assumption that annexin $\mathrm{V}$ was detected in regard to the Z-line, at the costamere level. Higher magnification of transverse sections clearly showed invaginations (arrows) containing $\mathrm{Na}^{+} / \mathrm{K}^{+}$-ATPase (Fig. 6C) or annexin V (Fig. 6F) suggesting that annexin $\mathrm{V}$ was localized at or near T-tubules, as previously
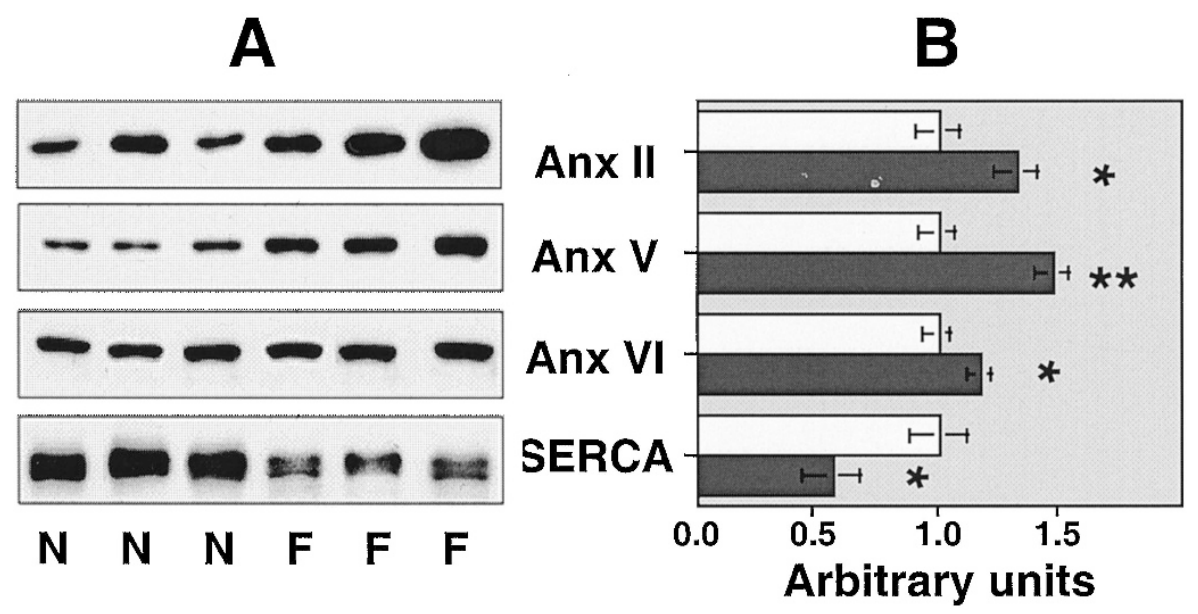

Figure 4.

Comparison of the amount of annexins II, V, and VI in nonfailing and failing hearts by Western blot analysis. A, Western blot analysis of annexin II (Anx II), annexin V $(A n x V)$, annexin VI $(A n x V)$, and sarco-endoplasmic reticulum $\mathrm{Ca}^{2+}$-ATPase (SERCA) in CPP samples (10 $\mu \mathrm{g}$ of protein) from nonfailing $(M)$ and failing $(F)$ hearts. $\mathrm{B}$, Relative amounts of annexins II, V, and VI and SERCA in nonfailing (light bars) and failing hearts (dark bars). Values are mean $\pm \operatorname{SEM}, n=9 ;{ }^{*} p<0.05,{ }^{* *} p<$ 0.01 , compared with nonfailing hearts. 

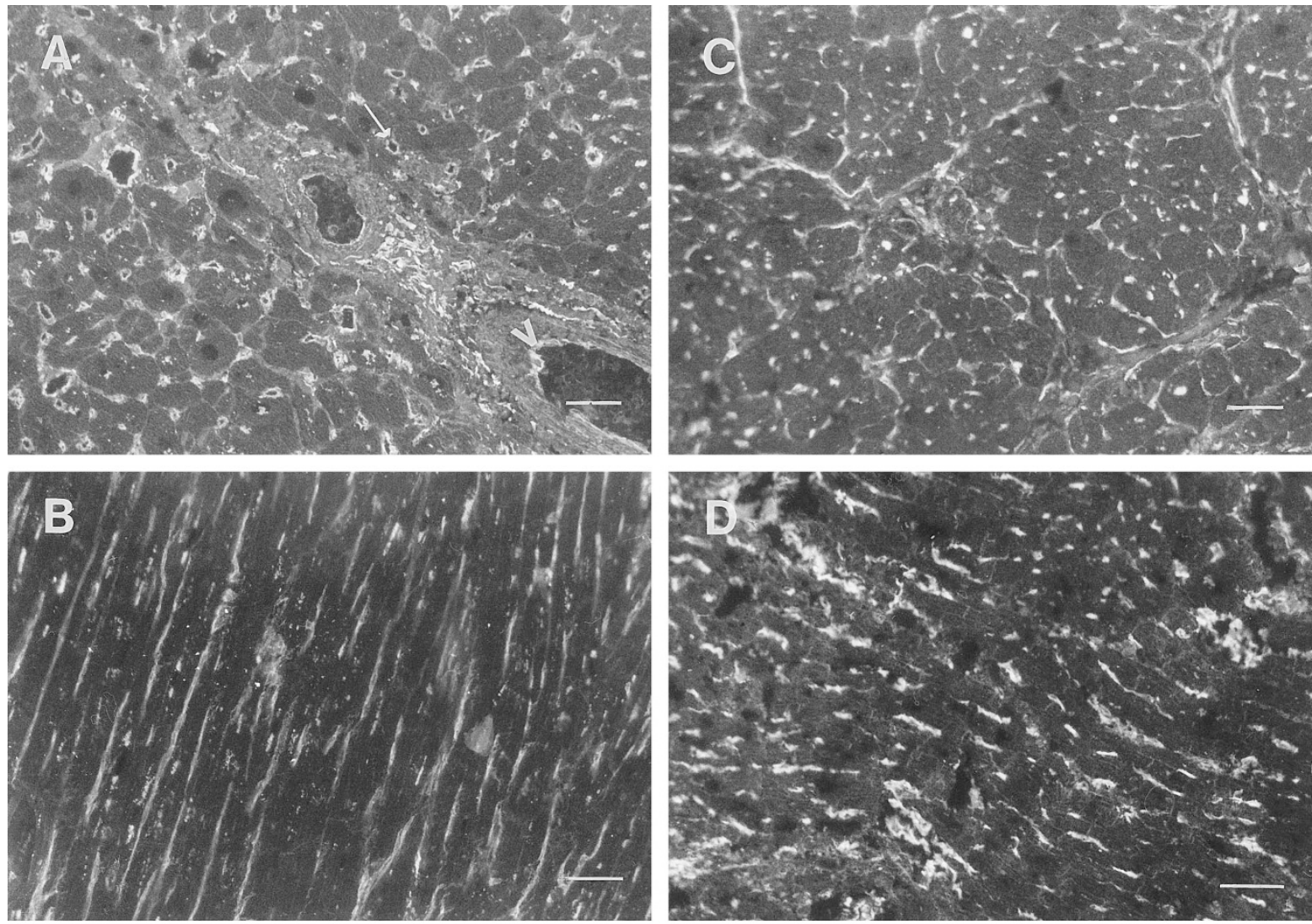

$\mathrm{N}$
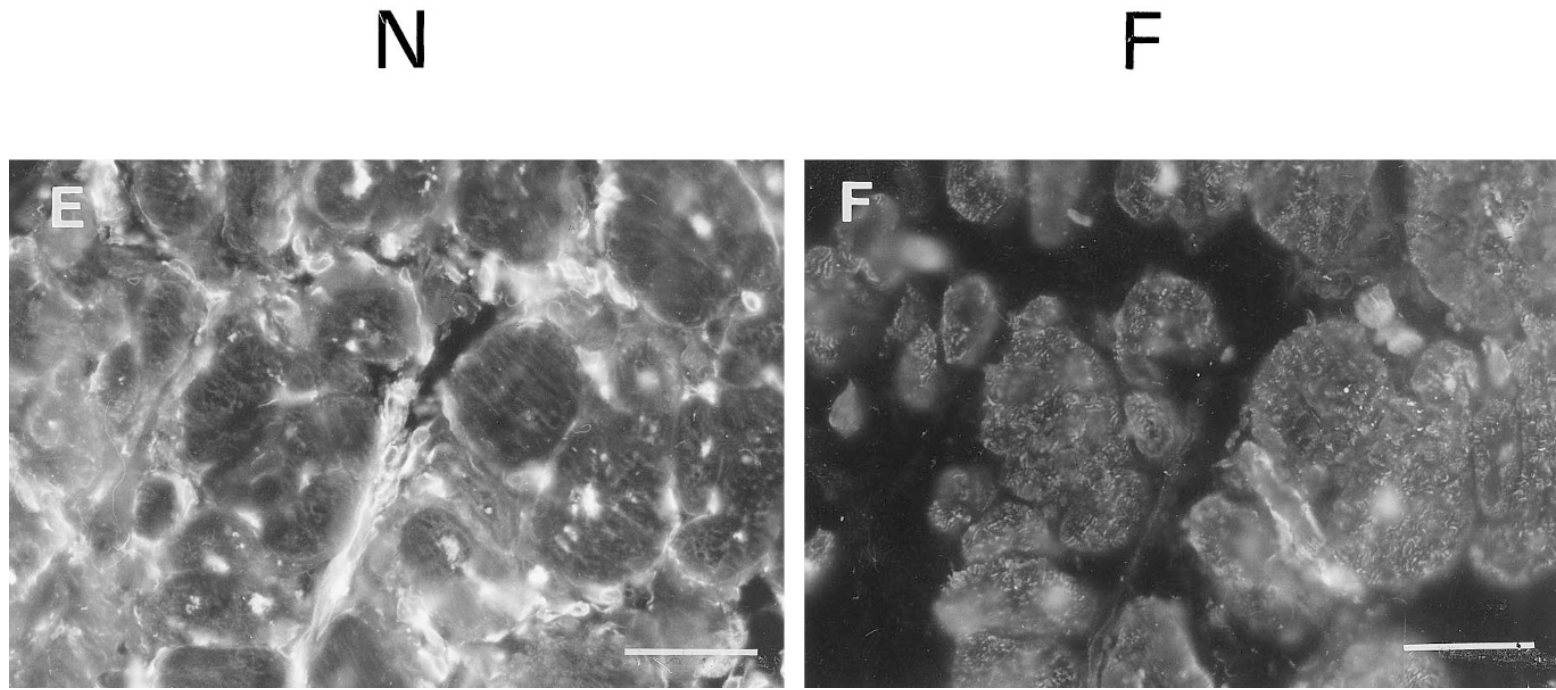

\section{Figure 5.}

Annexin II localization in nonfailing $(N)$ and failing $(F)$ hearts. Immunofluorescent labeling of annexin II in sections from nonfailing $(A$ and $B)$ and failing heart $(C$ and D). Double immunolabeling of annexin II and $\alpha$-actinin in transverse sections ( $\mathrm{E}$ and $\mathrm{F}$, respectively) of failing hearts. Arrow shows coronary vessels. Bar, $50 \mu \mathrm{m}$.

described for $\mathrm{Na}^{+} / \mathrm{K}^{+}$-ATPase (McDonough et al, 1996). At the same time, we cannot exclude annexin $V$ association with adjacent sarcoplasmic reticulum because on some sections the pattern appears as faint bands parallel to the longitudinal axis of myofibers resembling that of cardiotin, a sarcoplasmic reticulum protein (Schaart et al, 1997).

Differences in labeling of annexin $\mathrm{V}$ in nonfailing and failing hearts is shown in Figure 7. Both transverse (Fig. 7, A and D) and longitudinal (Fig. 7, B and E) sections showed that annexin $\mathrm{V}$ was mainly distributed at the level of sarcolemma in nonfailing hearts (as shown in Fig. 6) and was almost absent from T-tubules (Fig. 7D) and poorly labeled sarcolemma and intercalated discs (Fig. 7E) in failing hearts. Comparison of annexin $\mathrm{V}$ and $\alpha$-actinin distribution showed that in failing hearts, annexin $\mathrm{V}$ was predominantly present in patches of fibrosis between the bundles of myocytes (Fig. 7E) where no $\alpha$-actinin labeling (Fig. 7F) was detected. 

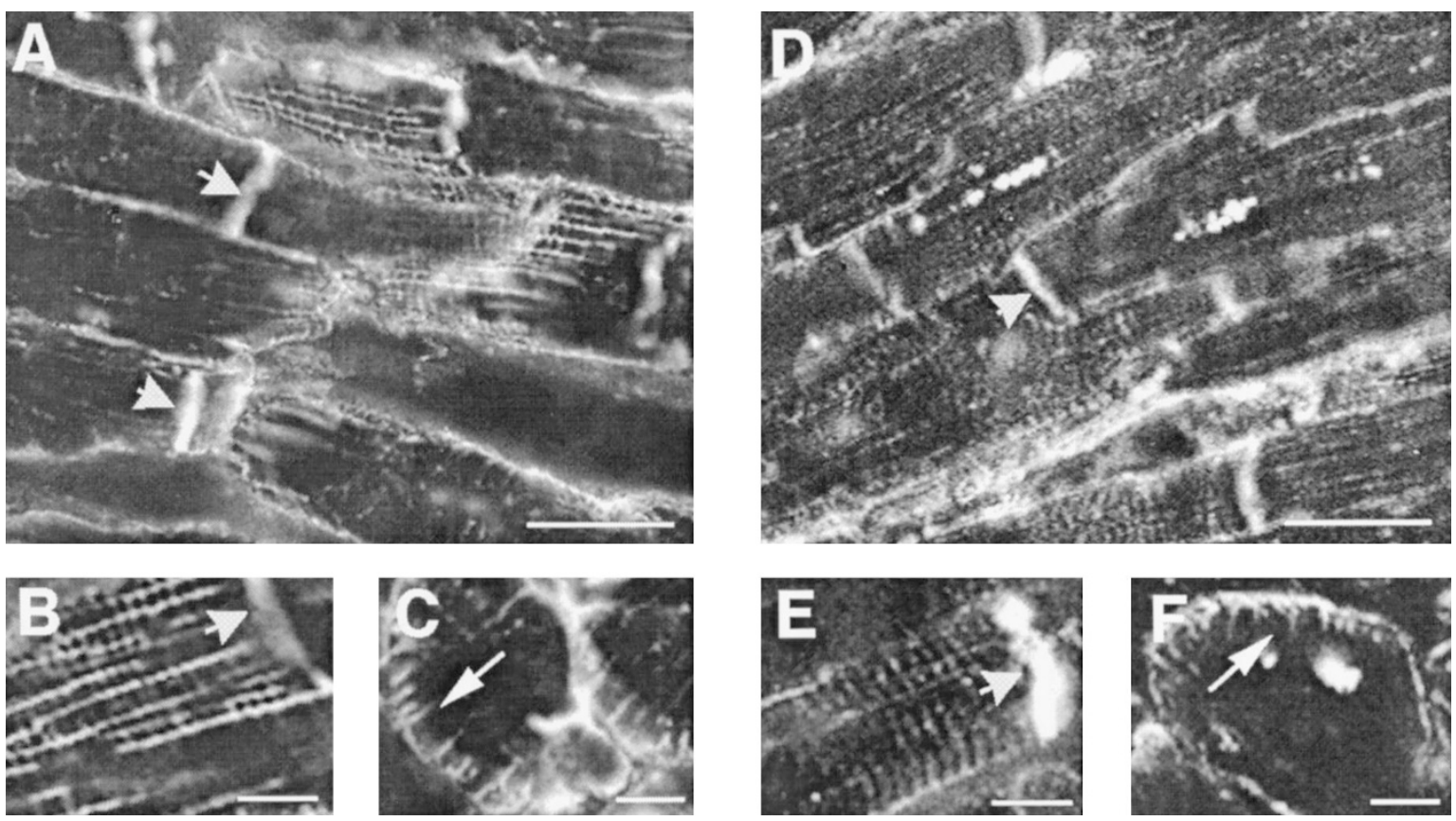

\section{Figure 6.}

$\mathrm{Na}^{+} / \mathrm{K}^{+}$-ATPase and annexin V localization in nonfailing hearts. Longitudinal sections of myocardium were labeled with antibodies to $\mathrm{Na}^{+} / \mathrm{K}^{+}$-ATPase $(\mathrm{A})$ and annexin $V(B)$. Intracellular staining patterns at higher magnification are shown in $B\left(\mathrm{Na}^{+} / \mathrm{K}^{+}\right.$-ATPase) and $E$ (annexin $\left.V\right)$. Transverse sections are shown in $C$ $\left(\mathrm{Na}^{+} / \mathrm{K}^{+}\right.$-ATPase) and $\mathrm{F}$ (annexin V). Arrows point to T-tubules and arrow heads to intercalated discs. Bar, $25 \mu \mathrm{m}(\mathrm{A}$ and $\mathrm{D})$; bar, $10 \mu \mathrm{m}(\mathrm{B}, \mathrm{C}, \mathrm{E}$, and $\mathrm{F})$.

Distribution of annexin VI in nonfailing and failing hearts is shown in Figure 8. Invaginations visible in transverse sections (Fig. 8A) and a striated pattern (Fig. 8B) coincident with $\alpha$-actinin labeling at the Z-line of myocytes (Fig. $8 \mathrm{C}$ ) suggested that annexin VI, like annexin $\mathrm{V}$ in nonfailing heart, was present at the level of sarcolemma, including T-tubules and intercalated discs. In failing hearts, invaginations of sarcolemma (Fig. 8D) and striated labeling of annexin VI (Fig. 8E) corresponding to that of $\alpha$-actinin (Fig. 8F) were still observed within the myocytes. In addition, transverse and longitudinal sections of failing hearts showed that annexin VI was present in interstitium, between the bundles of myofilaments revealed by $\alpha$-actinin staining (Fig. 8F).

\section{Discussion}

For the first time, the expression and the localization of annexins II, V, and VI were studied on the same samples of nonfailing and failing human hearts. We also demonstrated that in nonfailing human hearts annexins $\mathrm{V}$ and $\mathrm{VI}$ were present predominantly at the level of the myocyte membranes, whereas annexin II was mainly located in the interstitium. Myocardium from the patients with end-stage heart failure showed a significant increase in the expression of annexins II and $\mathrm{V}$, accompanied by a marked staining of annexin II, V, and VI in the interstitium. At the same time, annexin $\mathrm{V}$ staining of myocytes became hardly visible.

In the present study, we determined the absolute amount of annexins II, V, and VI in membraneenriched CPP from human myocardium and we showed that the amount of annexin $\mathrm{VI}$ was higher than that of annexin II and annexin V. The preparation was chosen because it contained most of the tissue annexins (Fig. 2) and because we assumed that annexins that are tightly associated with membranes, such as those forming the $\mathrm{Ca}^{2+}$ channel, are of special interest for cardiac pathology. Using this preparation, we found a higher amount of annexin $\mathrm{V}$ than previously reported for human hearts (Reutelingsperger et al, 1994), but our findings agreed with those reported for normal rat hearts (Giambanco et al, 1993; Jans et al, 1995, 1998). In addition, the amount of annexin VI in human heart was higher than reported in rat heart (Giambanco et al, 1993). It is likely that the use of CPP leads to the recovery of the higher yields observed in this study, whereas EGTA extraction was employed in other studies.

In failing hearts, our results showed an increase in mRNA and protein levels of annexin II and annexin V, and clearly established that the accumulation of mRNA and protein occurred in parallel, likely due to transcriptional regulation. This is consistent with data reported by Song et al (1998) for failing hearts, obtained from a mixed group of patients with coronary artery disease and cardiomyopathy. However, we also found an increase in annexin VI that was not detected by Song et al, probably because a substantial part of annexin VI was lost in the EGTA extracts used in their study. A similar increase in the amount of annexins II and $\mathrm{V}$, as well as of annexin $\mathrm{VI}$, was demonstrated in left ventricles from hypertensive guinea pigs at the onset of heart failure (Trouvé et al, 1999), whereas in compensated hypertrophy, the amounts of annexin $\mathrm{V}$ were unchanged (Jans et al, 1998), suggesting that 

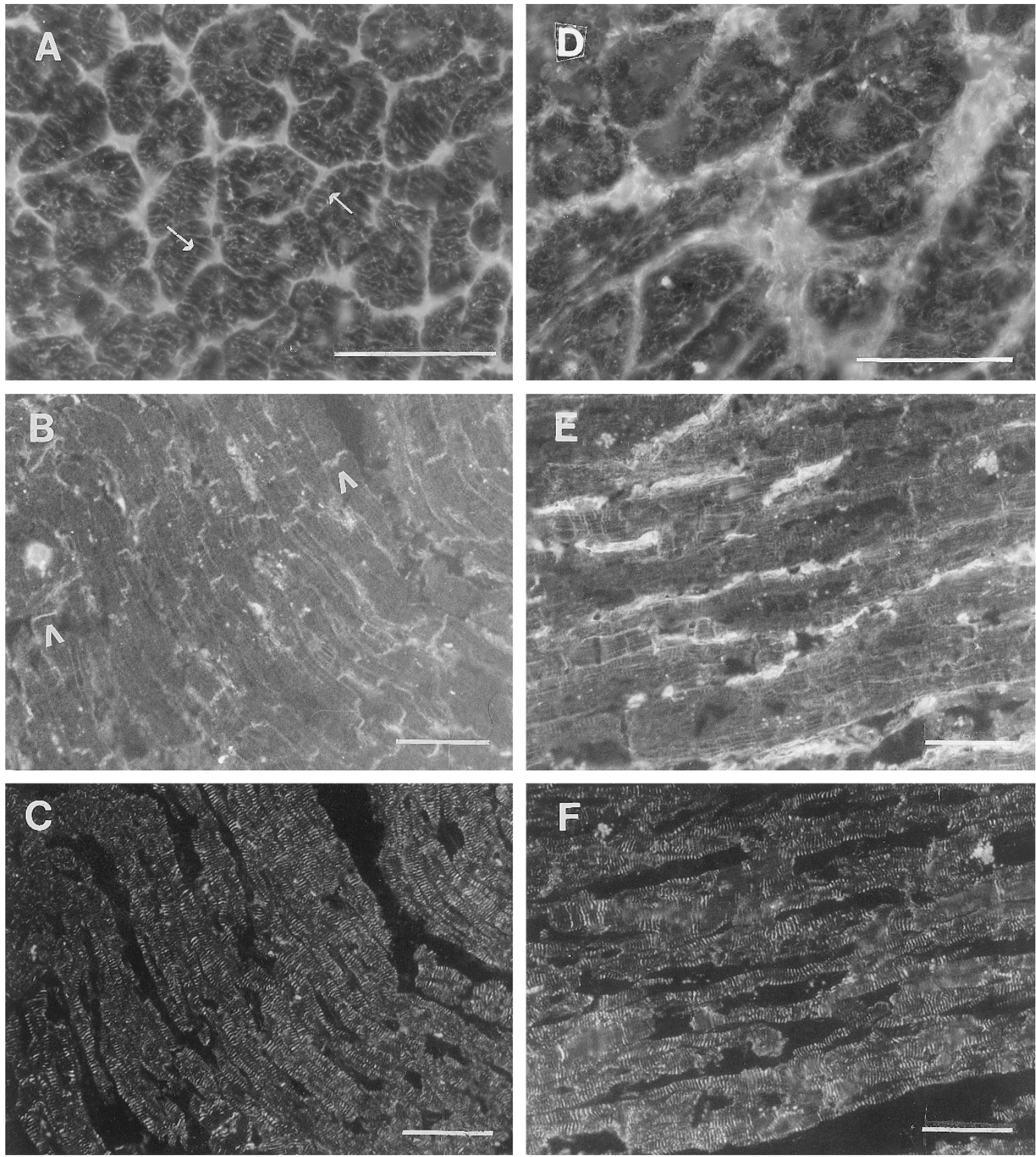

$\mathrm{N}$

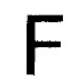

\section{Figure 7.}

Annexin $V$ localization in nonfailing $(M)$ and failing $(F)$ hearts. Immunohistofluorescence of transverse sections from nonfailing $(A)$ and failing heart $(D)$ labeled with antibodies to annexin $\mathrm{V}$. Double immunolabeling of annexin $\mathrm{V}$ and $\alpha$-actinin in longitudinal sections from nonfailing ( $\mathrm{B}$ and $\mathrm{C}$, respectively) and failing hearts ( $\mathrm{E}$ and $\mathrm{F}$, respectively). Arrows point to T-tubules and arrow heads to intercalated discs. Bar, $50 \mu \mathrm{m}$.

expression of annexins varies with severity of heart pathology.

To clarify the consequences of this upregulation of annexins in the failing heart, we further investigated their distribution. We have shown that annexin II was mainly localized in the vascular endothelial cells and in the extracellular matrix of human heart (Fig. 5) as well as of guinea pig heart (Trouvé et al, 1999). Parallel with the increase in annexin II mRNA and protein levels in failing hearts, there was an intense labeling of the interstitium between the cardiomyocytes (likely fibrotic tissue) and around the coronary arteries. Because annexin II is involved in membrane trafficking and extracellular matrix binding (Waisman, 1995), this 

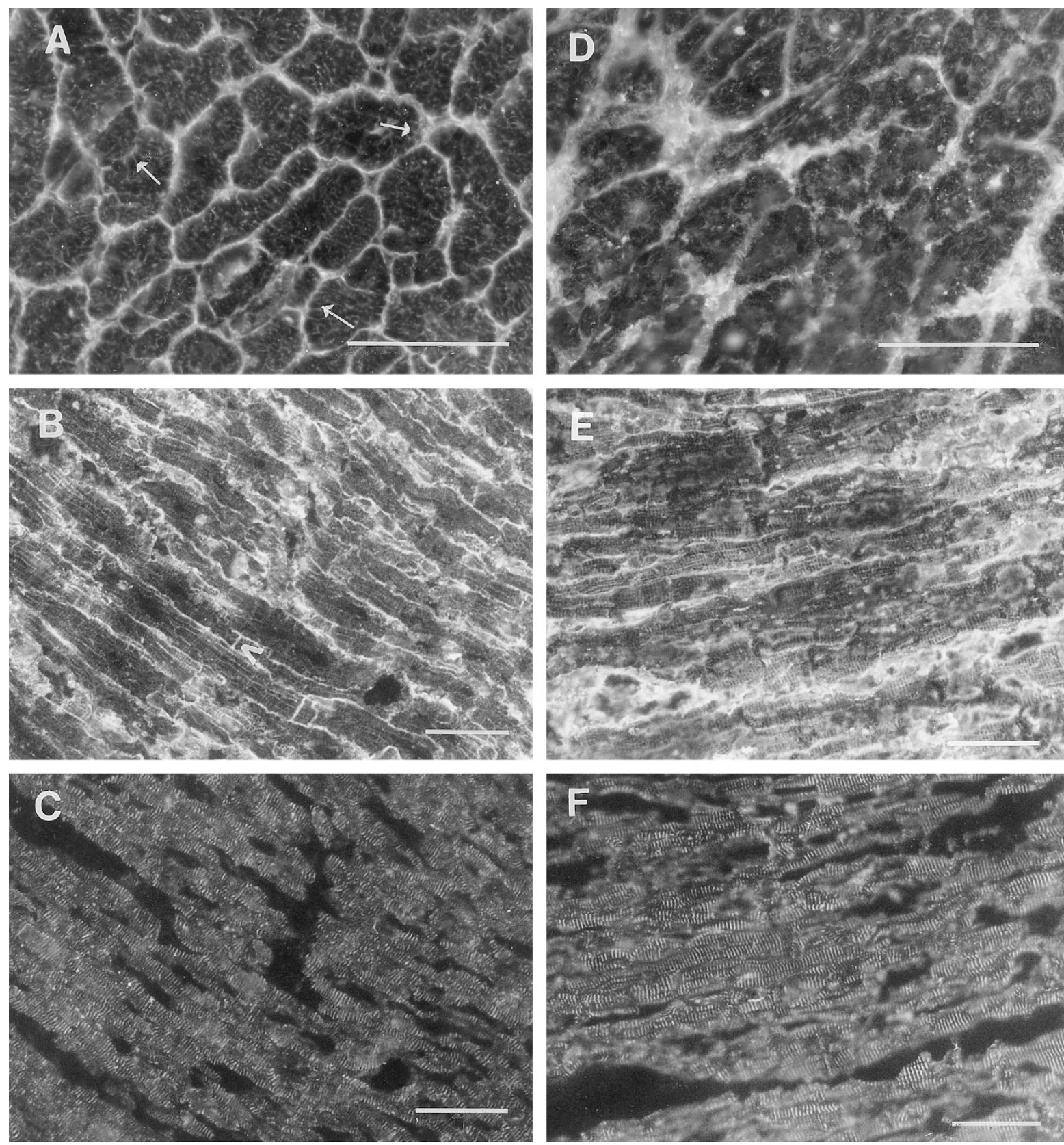

\section{$\mathrm{N}$}

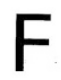

\section{Figure 8.}

Annexin VI localization in nonfailing $(M)$ and failing $(F)$ hearts. Immunohistofluorescence of transverse sections from nonfailing $(A)$ and failing heart $(B)$ labeled with antibodies to annexin VI. Double immunolabeling of annexin $\mathrm{VI}$ and $\alpha$-actinin in longitudinal sections from nonfailing (B and $\mathrm{C}$, respectively) and failing hearts ( $\mathrm{E}$ and $\mathrm{F}$, respectively). Arrows show invaginations of sarcolemma and arrow heads indicate intercalated discs. Bar, $50 \mu \mathrm{m}$.

would suggest that annexin II plays a role in the development of fibrosis and the organization of extracellular matrix in heart failure.

In this study, we described a high labeling of annexin $\mathrm{V}$ in the myocyte membranes of nonfailing human myocardium that was equivalent to that of $\mathrm{Na}^{+} / \mathrm{K}^{+}$-ATPase (Fig. 6). Taken together, our results indicated that annexin $\mathrm{V}$ was present in sarcolemma, and intercalated discs, and in the T-tubules connected to the terminal cisternae of sarcoplasmic reticulum -the complex in which the excitation-contraction coupling took place. Therefore, labeling of annexin $\mathrm{V}$ in human heart was similar to that of other species (Doubell et al, 1993; Jans et al, 1995; Luckcuck et al, 1997; Trouvé et al, 1999; Van Bilsen et al, 1992; Wang et al, 1995). Interestingly, immunofluorescence of annexin $\mathrm{V}$ in failing hearts (Fig. 7, D and E) was mainly observed in areas corresponding to fibrotic tissue. In 
contrast, the labeling of annexin $\mathrm{V}$ in sarcolemma, T-tubules, and intercalated discs became faint. In some sections of failing human heart it was even difficult to distinguish annexin $\mathrm{V}$ labeling from that of annexin II, because myocyte labeling was almost absent, whereas the interstitium became extensively stained (Fig. 7D). This relocalization is a striking feature of the failing human heart and is likely attributable to a diversity in pathological states because it is often observed in end-stage heart failure, rarely in guinea pig at the onset of heart failure (Trouvé et al, 1999), and not detected in compensated hypertrophy (Jans et al, 1998), although annexin $\mathrm{V}$ localization in normal cardiac tissue is very similar in both species. In any case it suggests the involvement of annexin $\mathrm{V}$ in the development of heart failure.

Despite the absence of signal sequences in annexin molecules there is accumulating evidence of their ability to be translocated and secreted out of cells (Takehara et al, 1994). A recent suggestion to the use serum level of annexin $\mathrm{V}$ as a marker for myocyte damage during myocardial infarction (Kaneko et al, 1996) could also argue for a potential secretion of annexin V. Taking into account the ability of annexin V to bind collagen and to regulate cell-extracellular matrix interactions (King et al, 1997; Raynal and Pollard, 1994), we suggested that an early relocalization of annexin $\mathrm{V}$ could participate in the remodeling of ventricular myocardium. Conversely, the decrease in myocyte membrane-bound annexin $\mathrm{V}$ could induce local shifts of $\mathrm{Ca}^{2+}$ concentration leading to activation of protein kinase C (Dubois et al, 1998) and phospholipase $\mathrm{A}_{2}$ (Mira et al, 1998), and/or activation of signaling pathways involved in cardiac remodeling (Sadoshima and Izumo, 1993).

In this study, we demonstrated that the content of annexin VI was higher than that of the annexins II and V. Annexin VI was mainly localized in myocytes at the level of the sarcolemma, T-tubules, and intercalated discs as in other mammalian species (lida et al, 1992; Trouvé et al, 1999; Wang et al, 1993) and was similar to that of annexins $\mathrm{V}$. In failing hearts, there was a slight increase in the amount of annexin VI, but unlike labeling with annexin $\mathrm{V}$, both myocytes and interstitial tissue were still labeled. Therefore, these results did not argue in favor of a specific role for annexin $\mathrm{VI}$ in the altered $\mathrm{Ca}^{2+}$ handling and remodeling during heart failure.

In conclusion, our results showed that annexins II, $\mathrm{V}$, and $\mathrm{VI}$ are abundant proteins of the human myocardium. Both quantification and localization of annexins in the failing human heart indicated an increase of the three annexins, and particularly of annexin $\mathrm{V}$, in fibrotic areas. The ability of annexin II and V to bind proteins of the extracellular matrix suggested that they play a role in the remodeling of the ventricular myocardium during heart failure. Furthermore, relocalization of annexin $\mathrm{V}$ from myocytes into the interstitial space may have important functional consequences, including changes in $\mathrm{Ca}^{2+}$ homeostasis and in $\mathrm{Ca}^{2+}$ signaling pathways, which in turn may participate to the impaired cardiac pump function in patients with end-stage IDCM.

\section{Materials and Methods}

\section{Tissue Samples}

Nine nonfailing hearts were obtained from adult patients who died from head trauma $(n=8)$ or smoke inhalation $(n=1)$. They were ultimately rejected for transplantation for reasons that were not related to their cardiac function.

Eleven failing hearts from patients with IDCM were obtained at the time of transplantation. All hearts exhibited morphological and histologic criteria of hypertrophy. The left ventricular ejection fraction was decreased to $16 \pm 2 \%(n=11)$. Transmural samples without visible signs of necrosis ( 0.5 to $2 \mathrm{~g}$ ) were quickly excised from the anterior free wall of the left ventricle and immersed in liquid nitrogen. This study was approved by the Consultative Committee for the Protection of Human Subjects in Biomedical Research at the Pitié-Salpétrière Hospital in Paris.

\section{Northern and Slot Blot Analyses of Annexin mRNA}

Total RNA from myocardium samples was prepared using an RNA plus kit (Bioprobe Systems, Montreuil sous Bois, France). The ratio of $18 \mathrm{~S}$ to $28 \mathrm{~S}$ bands and the yield of total RNA extracted were similar in both nonfailing and failing hearts.

cDNA probes of human annexin II (nucleotide 1 to 343) and human annexin $V$ (nucleotide 1 to 159) were subcloned in pBluescript $(S K+)$. The full-length annexin VI cDNA probe was inserted in PAT 153 plasmid and a 500 bp fragment was excised by EcoR 1-Pvull. Poly $(A+)$ RNA was detected by a 25 to 30 mer poly(T) synthetic oligonucleotide (Pharmacia, Les Ulis, France). The cDNA probes were labeled by random priming (Megaprime DNA Labeling System; Amersham, Les Ulis, France) with $\left(\alpha-{ }^{32} \mathrm{P}\right)$ dCTP (3000 $\mathrm{Ci} / \mathrm{mmol}$; NEN Life Science Products, Boston, Massachusetts) and the synthetic oligonucleotide was $5^{\prime}$ end-labeled with $\left(\gamma^{-32} \mathrm{P}\right)$ dATP $(6000 \mathrm{Ci} / \mathrm{mmol}, \mathrm{NEN})$.

Northern blots (25 $\mu \mathrm{g}$ RNA) and slot blots $(2,5,10$, and $20 \mu \mathrm{g}$ ) were performed according to the standard procedure described by Trouvé et al (1999). After washing, Northern and slot blots were exposed to a Phosphor screen for quantification with a BAS 1000 (FUJI Photo Film, Clichy, France) Bio-imaging Analyzer System. The results of densitometry were normalized to the total amount of poly $(A+)$ RNA to correct for sample loading.

\section{Characterization of Annexin II, V, and VI by Western Blot Analysis and Immunohistofluorescence}

CPP from myocardium samples $(200 \mathrm{mg})$ were obtained according to Sainte Beuve et al (1997) in the presence of protease inhibitors. Protein concentrations were determined by the method of Lowry et al (1951) using bovine serum albumin as a standard. 
CPP proteins were separated by electrophoresis in $10 \%$ polyacrylamide gels and then transferred to Hybond-P PVDF membrane (Amersham) (Towbin et al, 1979). Anti-annexin antibodies were obtained by immunization of a rabbit with recombinant human annexins (Trouvé et al, 1999). Monoclonal antibodies against dog cardiac SERCA have been described elsewhere (de la Bastie et al, 1990). The membranes were treated with antibodies diluted 1:5000 in blocking solution followed by the incubation with appropriate horseradish peroxydase-conjugated second antibodies diluted 1:5000 (Amersham). Peroxidase activity was detected by ECL using the ECLplus kit (Amersham). Coomassie blue staining of the total proteins was performed after stripping the membranes with 0.1 $\mathrm{M} / \mathrm{l}$ sodium acetate $(\mathrm{pH}=4)$ and $0.5 \mathrm{M} / \mathrm{l}$ sodium chloride. Quantification of both ECL spots on the film and Coomassie blue staining of proteins were performed by Gel Doc 1000 Molecular Analysis system (BioRad, Ivrys/Seine, France). ECL spots were normalized by integrated density of the Coomassie blue staining of the lane.

For immunohistofluorescence studies, samples of left ventricular myocardium were placed in embedding medium Tissue-Tek (Miles-Diagnostics, Elkhart, Indiana) and frozen in isopentane at $-155^{\circ} \mathrm{C}$. Frozen tissue sections $(7$ to $8 \mu \mathrm{m})$ were fixed with acetone:methanol ( $1: 1$ for 20 minutes at $\left.-20^{\circ} \mathrm{C}\right)$, saturated with $5 \%$ bovine serum albumin in PBS (30 minutes at room temperature), incubated with mouse monoclonal anti- $\alpha$-actinin antibodies (Sigma, Saint Quentin Fallavior, France) (1:50 in PBS for 30 minutes at $\left.37^{\circ} \mathrm{C}\right)$, washed, then incubated with appropriate dilutions of anti-annexin II, V, or VI antiserum (1:40, $1: 20$, and 1:20, respectively, in PBS for 30 minutes at $37^{\circ} \mathrm{C}$ ) or of anti- $\mathrm{Na}^{+} / \mathrm{K}^{+}$-ATPase antiserum (Charlemagne et al, 1994). After three rinses in PBS, the sections were successively incubated for 30 minutes at room temperature with a 1:50 dilution of anti-mouse immunoglobulins conjugated with Texas red and a 1:50 dilution of anti-rabbit immunoglobulins conjugated with fluoresceine isothiocyanate fluorochrome. Secondary antibodies alone did not reveal any significant fluorescence signal after the incubation with the tissue slices. Fluorescence was visualized using a Leica DM RD microscope equipped with epifluorescence optics.

\section{Statistical Analysis}

Results were expressed as mean \pm standard error of the mean (SEM). Differences between control and experimental groups were evaluated by a two-tailed unpaired Student's $t$ test, and $p<0.05$ was considered significant.

\section{Acknowledgements}

We are indebted to Pr. Gandgjbakch, Dr. Pavie, and Dr. Bors of Hôpital de la Pitiè-Salpetrière, Paris, France, for providing us with human myocardial sam- ples. We wish to thank Ms. B. Guilmart for improving the English text.

\section{References}

Charlemagne D, Orlowski J, Oliviero P, Rannou F, Sainte Beuve C, Swynghedauw B, and Lane LK (1994). Alteration of $\mathrm{Na}, \mathrm{K}-\mathrm{ATPase}$ subunit mRNA and protein levels in hypertrophied rat heart. J Biol Chem 269:1541-1547.

de la Bastie D, Levitsky D, Rappaport L, Mercadier JJ, MarotteF, Wisnewsky C, Brovkovich V, Schwartz K, and Lompre AM (1990). Function of the sarcoplasmic reticulum and expression of its $\mathrm{Ca}^{2+}$-ATPase gene in pressure overload-induced cardiac hypertrophy in the rat. Circ Res 66:554-564.

Doubell AF, Lazure C, Charbonneau C, and Thibault G (1993). Identification and immunolocalisation of annexins $\mathrm{V}$ and $\mathrm{VI}$, the major cardiac annexins, in rat heart. Cardiovasc Res $27: 1359-1367$.

Dubois T, Mira JP, Feliers D, Solito E, Russo-Marie F, and Oudinet JP (1998). Annexin V inhibits protein kinase $C$ activity via a mechanism of phospholipid sequestration. Biochem $\mathrm{J}$ 330:1277-1282.

Giambanco I, Verzini M, and Donato R (1993). Annexin V and VI in rat tissues during post-natal development: Immunochemical measurements. Biochem Biophys Res Commun 196:1221-1226.

Gunteski-Hamblin AM, Song G, Walsh RA, Frenzke M, Boivin GP, Dorn GW Kaetzel MA, Horseman ND, and Dedman JR (1996). Annexin VI overexpression targeted to heart alters cardiomyocyte function in transgenic mice. Am J Physiol 270:H1091-H1100.

Hasenfuss G, Reinecke H, Studer R, Meyer M, Pieske B, Holtz J, Holubarsch, C Posival H, Just H, and Drexler $\mathrm{H}$ (1994). Relation between myocardial function and expression of sarcoplasmic reticulum $\mathrm{Ca}^{2+}$-ATPase in failing and nonfailing human myocardium. Circ Res 75:434-442.

lida H, Hatate T, and Shibata Y (1992). Immunocytochemical localization of $67 \mathrm{kD} \mathrm{Ca}^{2+}$-binding protein (p67) in ventricular, skeletal, and smooth muscle cells. J Histochem Cytochem 1992:40: 1899-1907.

Jans SW, de Jong YF, Reutelingsperger CP, van der Vusse GJ, and van Bilsen M (1998). Differential expression and localization of annexin $\mathrm{V}$ in cardiac myocytes during growth and hypertrophy. Mol Cell Biochem 178:229-236.

Jans SWS, van Bilsen M, Reutelingsperger CPM, Borgers M, de Jong YF, and van der Vusse GJ (1995). Annexin V in the adult rat heart: Isolation, location and quantitation. J Mol Cell Cardiol 27:335-348.

Kaneko N, Matsuda R, Hosoda S, Kajita T, and Ohta Y (1996). Measurement of plasma annexin $\mathrm{V}$ by ELISA in the early detection of acute myocardial infarction. Clin Chim Acta 251:65-80.

King KB, Chubinskaya S, Reid DL, Madsen LH, and Mollenhauer $\mathrm{J}$ (1997). Absence of cell-surface annexin $\mathrm{V}$ is accompanied by defective collagen matrix binding in the swarm rat chondrosarcoma. J Cell Biochem 65:131-144.

Lowry OH, Rosebrough HJ, Farr AL, and Randall RJ (1951). Protein-measurement with the Pholin phenol reagent. J Biol Chem 183:263-275. 
Luckcuck T, Trotter PJ, and Walker JH (1997). Localization of annexin $\mathrm{V}$ in the adult and neonatal heart. Biochem Biophys Res Comm 238:622-628.

McDonough AA, Zhang Y, Shin V, and Frank JS (1996). Subcellular distribution of sodium pump isoform subunits in mammalian cardiac myocytes. Am J Physiol 270:C1221C1227.

Mira JP, Dubois T, Oudinet JP, Lukowski S, Russo-Marie F, and Geny $B$ (1998). Inhibition of cytosolic phospholipase $A_{2}$ by annexin $\mathrm{V}$ in differentiated permeabilized HL-60 cells: Evidence of crucial importance of domain I type II $\mathrm{Ca}^{2+}$ binding site in the mechanism of inhibition. J Biol Chem 272:10474-10482.

Pollard HB, Guy HR, Arispe N, Delafuente M, Lee G, Rojas EM, Pollard JR, Srivastava M, Zhang-Keck ZY, Merezhinskaya N, Caohuy H, Burns AL, and Rojas E (1992). Calcium channel and membrane fusion activity of synexin and other members of the annexin gene family. Biophys $\mathrm{J} 62: 15-18$.

Pula G, Bianchi R, Ceccarelli P, Giambanco I, and Donato R (1990). Characterization of mammalian heart annexins with special reference to CaBP 33 (annexin V). FEBS Lett 277:5358.

Raynal P and Pollard HB (1994). Annexins: The problem of assessing the biological role for a gene family of multifunctional calcium- and phospholipid-binding proteins. Biochim Biophys Acta 1197:63-93.

Reutelingsperger CP, van Heerde W, Hauptmann R, Maassen C, van Gool RG, de Leeuw P, and Tiebosch A (1994). Differential tissue expression of annexin VIII in human. FEBS Lett 349:120-124.

Sadoshima J and Izumo S (1993). Signal transduction pathways of angiotensin II-induced c-fos gene expression in cardiac myocytes in vitro. Circ Res 73:424-438.

Sainte Beuve C, Allen PD, Dambrin G, Rannou F, Marty I, Trouvé P, Bors V, Pavie A, Gandgjbakch I, and Charlemagne D (1997). Cardiac calcium release channel (ryanodine receptor) in control and cardiomyopathic human hearts: mRNA and protein contents are differentially regulated. J Mol Cell Cardiol 29:1237-1246.

Schaart G, Moens L, Endert JM, and Ramaekers FC (1997). Biochemical characterization of cardiotin, a sarcoplasmic reticulum associated protein. FEBS Lett 403:168-172.

Schelling JR, Gentry GJ, and Dubyak GR (1996). Annexin II inhibition of $G$ protein-regulated inositol trisphosphate formation in rat aortic smooth muscle. Am J Physiol 270:F682F690.
Song G, Campos B, Wagoner LE, Dedman JR, and Walsh RA (1998). Altered cardiac annexin mRNA and protein levels in the left ventricle of patients with end-stage heart failure. $J$ Mol Cell Cardiol 30:443-451.

Song G, Kirkpatrick DL, Gunteski-Hamblin AM, Dorn GW, Dedman JR, and Walsh RA (1995). Abnormal $\mathrm{Na}^{+} / \mathrm{Ca}^{2+}$ exchanger activity in transgenic mice with cardiac specific overexpression of annexin VI. Circulation 92(Suppl):I6971698.

Takehara K, Uchida S, Marumoto N, Asawa T, Osugi S, Kurusu S, Hashimoto I, and Kawaminami M (1994). Secretion of recombinant rat annexin $\mathrm{V}$ by insect cells in a baculovirus expression system. Biochem Biophys Res Comm 200:14211427.

Towbin H, Staehelin T, and Gordon J (1979). Electrophoretic transfer of proteins from polyacrylamide gels to nitrocellulose sheets: Procedure and some applications. Proc Natl Acad Sci USA 76:4350-4354.

Trotter PJ, Orchard MA, and Walker J H (1995). Ca ${ }^{2+}$ concentration during binding determines the manner in which annexin V binds to membranes. Biochem J 308:591-598.

Trouvé P, Legot S, Belikova I, Marotte F, Benevolensky D, Russo-Marie F, Samuel JL, and Charlemagne D (1999). Localization and quantification of cardiac annexins II, V, and VI in hypertensive guinea pigs. Am J Physiol 276:H1159H1166.

Van Bilsen M, Reutelingsperger CP, Willensem PH, Reneman RS, and Van der Gusse GJ (1992). Annexins in cardiac tissue: Cellular localization and effect on phospholipase activity. Mol Cell Biochem 116:95-101.

Waisman DM (1995). Annexin II tetramer: Structure and function. Mol Cell Biochem 149/150:301-322.

Wang L, lida H, and Shibata $Y$ (1993). Characterisation and localisation of a $67 \mathrm{kDa}$ calcium binding protein (p67) isolated from bovine hearts. Cardiovasc Res 27:1855-1862.

Wang L, Rahman MM, lida H, Inai T, Kawabata S, Iwanaga S, and Shibata $Y$ (1995). Annexin V is localized in association with Z-line of rat cardiac myocytes. Cardiovasc Res 30:363371.

Zeng FY, Gerke V, and Gabius HJ (1993). Identification of annexin II, annexin VI and glyceraldehyde-3-phosphate dehydrogenase as calcyclin-binding proteins in bovine heart. Int J Biochem 25:1019-1027. 